\title{
Tannin and in vitro digestibility of tropical browse: Predictive equations
}

\author{
NANCY LOU CONKLIN
}

\begin{abstract}
Author is a post-doctoral research assistant/animal nutritionist, Anthropology Department, Peabody Museum, Harvard University, Cambridge, Mass. 02138. At the time of the research, she was a graduate student, Animal Science Department, Cornell University.
\end{abstract}

\begin{abstract}
Summative equations to predict digestibility of tropical browse species for cattle were tested by comparison to in vitro digestibility. Four equations were used for the comparison: first the 2 Van Soest equations, 1 using sulfuric acid lignin and the other using permanganate lignin, neither of which have a correction for tannins. And second, the 2 Horvath equations, each using 10 the 2 above mentioned lignin values and both include a value for tannin content. The Van Soest equation using permanganate lignin and the Horvath equation using sulfuric acid lignin predicted the in vitro digestibilities of the leaf species quite well ( $r=0.89$ for both). The same Horvath equation predicted the digestibility of the high tannin species better than the Van Soest equation $(r=0.93$ versus 0.84). For initial evaluation and ranking of browse species suitable for future research efforts, either equation suitable.
\end{abstract}

Key words: condensed tannins, radial diffusion, neutral-detergent fiber, acid-detergent fiber, Guanacaste, Costa Rica.

Tannins affect digestibility to varying degrees depending on tannin type, animal species, and nutrients measured (Nastis and Malechek 1988, Robbins et al. 1991, Hanley et al 1992). Cattle are less adapted to tanniniferous fodders than deer or goats (Kumar and Singh 1984, Robbins et al. 1987a, b),particularly because they lack tannin binding proteins in their saliva (Austin et al. 1989, Mehansho et al. 1992). The ability to predict the digestibility of tanniniferous feeds for cattle, from chemical analysis, would be useful for rapid screening of potential fodder trees.

Predicting digestibility depends on the identification of feed fractions that consistently affect digestibility, in particular lignification and lignocellulose ratios (Van Soest 1982). Horvath (1981), however, found that lignin accounted for only $52 \%$ of the variation in the in vitro cell wall digestibility (IVCWD) of 7 species of maple tree leaves. Browse forages present the additional problem of tannins. Some portion of the tannins in a plant remains in the fiber fractions during analysis. Condensed tannins can contaminate the cell wall (the neutral-detergent fiber), the acid-detergent fiber, and the lignin (Reed 1987, McArthur 1988). The insoluble proanthocyanidins present in the cell wall were negatively correlated with cell wall digestibility (Reed 1986). Some of the condensed tannins, however, are believed to be solubilized in both the neutral-detergent and acid-detergent reagents (Horvath 1981).

The aim of this paper is to evaluate the detergent system of fiber

\footnotetext{
The author would like to thank Ellen Dierenfeld, Charlie Robbins, and Ann Hagerman for reviewing this manuscript. Thanks also to Jimmy Robertson, Peter Van Soest, and Margot Griswold for their help on lab methods.

Manuscript accepted 8 Jan. 1994.
}

analysis (Goering and Van Soest 1970, Robertson and Soest 1980) and the original predictive equations to provide an estimate of browse digestibility. Horvath (1981) developed predictive equations for high tannin maple leaves, based on sequential detergent extractions. This paper also tests whether Horvath's (1981) equations, developed from 1 tree genus, have a broader application to other genera of browse, particularly tropical browse.

\section{Methods}

Selection of the species studied was based on farmer recommendations and field observations of browsing range cattle at 2 sites in Guanacaste, Costa Rica. The climate has a strong 6 months wet/6 months dry cycle, with 2-3 weeks dry in the middle of a rainy season. Sixteen species seen browsed at varying frequencies were chosen, and an additional 6 species that were common but rarely observed as browsed by cattle were included on the leaf sampling (Conklin 1987; Table 1). The total sampling included 15 leguminous species and 7 non-legumes. Individual trees sampled were chosen at random according to standard plant ecology sampling methods (Oosting 1948) by placing line transects up hedgerows or selecting coordinates in forest quadrates on Hacienda La Pacifica, Cañas, Guanacaste. Leaves were harvested according to selective consumption by cattle; some trees possessed very large leaflets and their petioles were avoided by the cattle, those petioles were categorized as twigs, even though botanically they are not twigs.

Trees were sampled throughout the rainy season. All samples were used to test the Van Soest and Horvath equations, but only those from the end of the rainy season were used for further analysis of tannins using the following methods: condensed tannins or proanthocyanidins were measured by the butanol/HCl method described by Bate-Smith (1975) and modified by Porter et al. (1986), the radial diffusion assay quantified total tannins (Hagerman 1987), and paper chromatography, as described by Mole and Waterman (1987) using Forestal as the solvent. Both condensed tannins and total tannins were standardized with purified quebracho tannin (Asquith and Butler 1985) and the results reported as quebracho equivalents. Acid-detergent insoluble protein (acid-detergent insoluble nitrogen $\times$ 6.25) was determined by performing a Kjeldahl crude protein analysis on the acid-detergent fiber.

Each seasonal sample of a species was a composite from 10 trees, pooled to make 1 sample per period to control for variation of phenolic content within a species (Waterman et al. 1984) and to minimize labor. Twigs of $1-\mathrm{cm}$ diameter were collected and all the leaves associated with that pulled off and placed in a plastic bag. The twigs were then cut up and placed into a second plastic bag. The 2 fractions were analyzed separately. This twig size was selected because the twigs can be chopped by a small stationary chopper (Conklin 1987) and consumed with the leaves when fed in a trough to cattle, however twigs 
are not consumed by free-ranging cattle. All plant samples were dried in a forced-air oven at $55^{\circ} \mathrm{C}$ and ground through a Wiley Mill and a 1mm screen.

The sequential cell wall extractions described by Horvath (1981) and Conklin (1987) were performed: 1 subsample, in duplicate, was extracted in neutral-detergent reagent and the result in residue extracted in acid-detergent reagent, as usual (Robertson and Van Soest 1980). The resulting residue was referred to as NAD in the following equations. Then a second subsample, also in duplicate, was extracted first in acid-detergent reagent and the resulting residue extracted in neutral-detergent reagent. This resulting residue was referred to as AND in the following equations. Sodium sulfite was not used in the neutral-detergent reagent.

Horvath found the [acid-detergent fiber (ADF) remaining after preextraction with neutral-detergent] minus [the neutral detergent fiber (NDF) remaining after the pre-extraction with acid-detergent], or NAD minus AND, was the most predictive "tannin" fraction to correct calculated digestibility of tanniniferous browses. Sulfuric acid lignin (Ls) and permanganate lignin (Lk) were both determined on separate sub-samples. The following equations were used to calculate the predicted digestibilities:

1. from Goering and Van Soest (1970): using sulfuric acid lignin values:

A. Digestibility $=0.98(100-\mathrm{NDF})+\mathrm{NDF}\left(147.3-78.9 \log _{10}((\mathrm{Ls} / \mathrm{ADF})\right.$ 100)) using permanganate lignin values:

B. Digestibility $=0.98(100-\mathrm{NDF})+\mathrm{NDF}\left(180.8-96.6 \log _{10}((\mathrm{Lk} / \mathrm{ADF})\right.$
100))

2. from Horvath (1981):

C. Digestibility $=0.98(100-\mathrm{NDF})+\mathrm{NDF}\left(181.3-96.6 \log _{10}((\mathrm{Ls} / \mathrm{ADF}) 100)\right.$ $0.7(($ NAD-AND)/ADF) 100))

D. Lk substituted for $L s$

The calculated digestibilities were regressed against in vitro true digestibility [Tilley and Terry (1963) as modified by Goering and Van Soest (1970)] and the correlation coefficients determined (DeltaGraph Inc. 1992). Neutral-detergent solution was used to dissolve the microbial residue instead of pepsin. The rumen inoculum camc from a Holstein cow fed timothy hay. The rumen fluid was blended, under nitrogen gas, and quickly (to prevent cooling) strained through cheese cloth and then glass wool. The tannin levels obtained by the different techniques were correlated against in vitro digestibility as well as each other using DeltaGraph Inc. (1992). Statview SE + Graphics (1991) was used to calculate t-tests, which are unpaired and two-tailed unless otherwise specified.

\section{Results}

Observed in vitro true digestibilities for leaves ranged from 14.8 to $82.0 \%$ (Table 1), and for twigs from 18.7 to $44.8 \%$ (Table 2). Calculated (predicted) digestibilities for leaves with low $(<45 \%)$ and intermediate $(45-60 \%)$ digestibility, were not significantly different from the in vitro digestibilities obtained $(t=-1.1, \mathrm{p}=0.26)$. Species with high ( $>60 \%$, see lower third of Table 1$)$ in vitro digestibility tended to be underestimated by the predicted digestibility, but not significantly $(t=1.9, p=0.06)$. Calculated values for digestion of twigs

Table 1. In vitro true digestibility (IVTD) percentages, on a dry matter basis, of Costa Rican browse leaves, compared to calculated (predicted) digestibilities (PD) based on 4 different equations. The PDs collectively for all the leaves are not significantly different from the IVTDs $(t=0.026, p=$ 0.979). Species listed by increasing IVTD.

\begin{tabular}{|c|c|c|c|c|c|c|}
\hline \multirow[b]{2}{*}{ species } & \multirow[b]{2}{*}{$\mathbf{n}$} & \multirow[b]{2}{*}{ in vitro digestibility } & \multicolumn{4}{|c|}{ Predicitive Equations } \\
\hline & & & V-Lsw* & V-Lk & H-Ls & H-Lk \\
\hline & & - $(\%)-\cdots$ & - $\cdots \cdots$ & 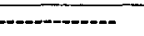 & & \\
\hline Andira inermis (Swarts) H.B.K. & 1 & 14.8 & 25.7 & 40.8 & 19.6 & 31.9 \\
\hline Lonchocarpus minimiflorus Donn-Smith* & 3 & 33.4 & 47.6 & 44.2 & 37.6 & 30.7 \\
\hline Hymenaea courbaril L.* & 1 & 33.4 & 39.3 & 45.9 & 33.6 & 37.5 \\
\hline Enterolobium cyclocarpum (Jacq.)Griseb. & 2 & 39.8 & 44.2 & 44.9 & 35.5 & 33.5 \\
\hline Piscidia carthagenensis Jacq. & 3 & 42.2 & 51.2 & $47.6^{\prime}$ & 48.0 & 39.6 \\
\hline Bauhinia ungulata L. & 3 & 44.9 & 58.6 & 56.8 & 52.5 & 47.3 \\
\hline Cordia allioidora (R.\&P.)Cham. & 2 & 45.7 & 54.0 & 47.7 & 43.8 & 33.3 \\
\hline Pithecellobium saman (Jacq.)Benth. & 2 & 47.3 & 51.6 & 57.4 & 51.0 & 54.6 \\
\hline Guazuma ulmifolia Lam. & 3 & 48.0 & 55.3 & 53.0 & 53.7 & 48.0 \\
\hline Cajanus cajan (L.)Millsp. & 1 & 49.0 & 52.9 & 46.2 & 47.0 & 37.4 \\
\hline Ficus sp. & 2 & 49.9 & 49.5 & 56.6 & 47.9 & 53.7 \\
\hline Tamarindus indica L. & 2 & 50.9 & 60.2 & 54.5 & 49.8 & 39.9 \\
\hline Tabebuia ochracea (Cham.)Standl. & 3 & 54.2 & 54.6 & 52.2 & 51.9 & 45.3 \\
\hline Mangifera indica $\mathbf{L}$. & 2 & 58.0 & 61.2 & 60.3 & 56.9 & 52.2 \\
\hline mean $\pm \mathrm{SD}$ & & $43.7 \pm 10.9$ & $50.4 \pm 9.3$ & $50.6 \pm 6.0$ & $44.9 \pm 10.1$ & $41.8 \pm 8.3$ \\
\hline Acacia farnesiana (L.)Willd & 2 & 65.1 & 56.7 & 62.6 & 46.4 & 49.1 \\
\hline Caesalpinia eriostachys Benth.* & 1 & 66.5 & 69.4 & 68.2 & 70.3 & 65.9 \\
\hline Hemiangium excelsum A.C. Sm. & 1 & 67.0 & 75.7 & 58.7 & 62.4 & 40.3 \\
\hline Gliricidia sepium (Jacq.)Stend. & 3 & 68.2 & 63.5 & 61.2 & 59.2 & 53.5 \\
\hline Spondias purpurea L. & 2 & 69.3 & 68.8 & 67.6 & 66.8 & 62.7 \\
\hline Lysiloma divaricata+ & 3 & 69.4 & 69.5 & 65.9 & 66.8 & 60.4 \\
\hline Cassia bicapsularis L.* & 1 & 71.5 & 68.3 & 67.9 & 64.6 & 60.3 \\
\hline Myrospermus frutescens Jacq. ${ }^{*}$ & 3 & 82.0 & 75.1 & 73.5 & 75.5 & 70.5 \\
\hline mean $\pm S D$ & & $69.9 \pm 5.3$ & $68.4 \pm 6.1$ & $65.7 \pm 4.7$ & $64.0 \pm 8.7$ & $57.8 \pm 9.7$ \\
\hline
\end{tabular}

* generally not preferred

+ Formerly L seemannii Britt. \& Rose

** the Predictive Equations: V-Ls = Van Soest equation using sulfuric acid lignin; V-Lk = Van Soest equation using permanganate lignin

$H-L s=$ Horvath equation using sulfuric acid lignin; $H-L k=$ Horvath equation using permanganate lignin

The top 14 species are the low $(>45 \%)$ and medium $(45-60 \%)$ digestibilities, the bottome 8 species are the high (>60\%) digestibility species. 
Table 2. In vitro true digestibility (IVTD) percentage, on a dry matter basis, of Costa Rican twigs compared to calculated (predicted) digestibilities (PD) based on 4 different equations. The PDs collectively are significantly higher than the IVTD $(t=-\mathbf{8 . 5}, p=0.0001)$. Genera listed by increasing IVTD.

\begin{tabular}{|c|c|c|c|c|c|c|}
\hline \multirow[b]{2}{*}{ species } & \multirow[b]{2}{*}{$\mathbf{n}$} & \multirow[b]{2}{*}{ in vitro digestibility } & \multirow[b]{2}{*}{ V-Ls** } & \multicolumn{2}{|c|}{ Predicitive Equations } & \multirow[b]{2}{*}{ H-Lk } \\
\hline & & & & V-Lk & H-Ls & \\
\hline & & $(\%)-\cdots$ & & ----n-.- & \%)--------- & \\
\hline Andira inermis & 1 & 18.7 & 33.3 & 38.6 & 33.9 & 35.5 \\
\hline Bauhinia ungulata & 3 & 19.9 & 45.6 & 45.8 & 49.2 & 43.3 \\
\hline Tabebuia ochracea & 3 & 22.8 & 41.1 & 44.7 & 42.9 & 40.4 \\
\hline Tamarindus indica & 2 & 23.9 & 45.0 & 45.2 & 49.2 & 43.8 \\
\hline Guazuma ulmifola & 3 & 27.4 & 51.9 & 56.5 & 54.6 & 53.1 \\
\hline Gliricidia sepium & 3 & 27.8 & 48.5 & 45.7 & 52.3 & 42.7 \\
\hline Pithecellobium saman & 2 & 28.3 & 48.6 & 44.8 & 51.7 & 42.0 \\
\hline Myrospermum frutescens & 3 & 28.8 & 49.5 & 46.3 & 53.0 & 42.8 \\
\hline Cordia alliodora & 2 & 29.0 & 53.5 & 30.9 & 54.5 & 24.9 \\
\hline Enterolobium cyclocarpum & 2 & 29.9 & 45.8 & 43.4 & 50.5 & 41.8 \\
\hline Lonchocarpus minimiflorus & 3 & 30.3 & 46.0 & 44.3 & 48.9 & 41.0 \\
\hline Spondias purpurea & 1 & 31.3 & 45.8 & 46.4 & 43.1 & 37.9 \\
\hline Ficus sp. & 2 & 31.7 & 42.6 & 45.1 & 46.3 & 47.0 \\
\hline Lysiloma divaricata & 3 & 32.1 & 51.7 & 49.5 & 56.2 & 48.1 \\
\hline Cassia bicapsularis & 1 & 34.3 & 51.7 & 44.1 & 55.5 & 41.1 \\
\hline Hymenaea courbaril & 1 & 34.7 & 49.2 & 50.3 & 51.5 & 48.5 \\
\hline Cajanus cajan & 1 & 36.3 & 59.3 & 29.0 & 63.6 & 25.5 \\
\hline Piscidia carthagenensis & 3 & 37.9 & 49.8 & 47.0 & 52.1 & 43.1 \\
\hline Caesalpinia eriostachys & 1 & 38.9 & 63.4 & 51.5 & 69.0 & 48.7 \\
\hline Mangifera indica & 2 & 44.8 & 59.3 & 40.7 & 59.5 & 35.9 \\
\hline mean $\pm S D$ & & $30.4 \pm 6.4$ & $49.1 \pm 6.8$ & $44.5 \pm 6.3$ & $51.9 \pm 7.5$ & $41.3 \pm 7.0$ \\
\hline
\end{tabular}

**the Predictive Equations:

V-Ls = Van Soest equation using sulfuric acid lignin; V-Lk = Van Soest equation using permanganate lignin

H-Ls = Horvath equation using sulfuric acid lignin; $H$ - Lk = Horvath equation using permanganate lignin

Acacia farnesiana and Hemiangium excelsum twigs were not analyzed.

were significantly higher than in vitro digestibility $(t=-8.5, p=$ 0.0001 ), indicating that some important deterrent of digestibility was not estimated by any of the methods for calculating the digestibility of twigs.

I used simple linear correlations (Table 3) to compare predicted digestibility and in vitro digestibility of all leaves, and for various categories of species. Results showed that the predicted digestibilities were highly correlated to in vitro digestibilities for leaves, but low for twigs. Additionally, Van Soest's equation using permanganate lignin or Horvath's equation using sulfuric acid lignin were the 2 best predictors of in vitro digestibility ( $r=0.89$ for both) when tanniniferous and nontannin species were combined. The same Horvath equation predicted the digestibility of the higher tannin species better than the

Table 3. Correlations between in vitro true digestibility (IVTD of Costa Rican Browse leaves and the 4 different predicted (calculated) digestibilites (PD).

\begin{tabular}{lcllc}
\hline & V-Ls & V-Lk & H-Ls & H-Lk \\
\hline leaf category & $\mathrm{r}$ & $\mathrm{r}$ & $\mathrm{r}$ & $\mathrm{r}$ \\
all leaves & 0.877 & 0.890 & $0.892+$ & 0.818 \\
mature & 0.905 & $0.939+$ & 0.852 & 0.825 \\
young & 0.766 & $0.909+$ & 0.823 & 0.852 \\
CT & 0.900 & 0.836 & $0.931+$ & 0.716 \\
non-CT & 0.840 & $0.934+$ & 0.822 & 0.896 \\
& & & & \\
twig category & & & & \\
all twigs & $0.650+$ & 0.005 & 0.591 & 0.006 \\
CT & $0.680+$ & 0.086 & 0.585 & 0.145 \\
non CT & 0.600 & 0.173 & $0.616+$ & 0.249
\end{tabular}

best prediction $=+$

$\mathrm{CT}=$ species not containing condensed tannins;

nonCT $=$ species not containing condensed tannins, hydrolyzable tannins unmeasured

V-Ls = PD by Van Soest sulfuric acid lignin equation correlated to IVTD

V-LK = PD by Van Soest permanganate lignin equation correlated to IVTD

H-Ls = PD by Horvath sulfuric acid lignin equation correlated to IVTD;

H-Lk = PD by Horvath permanganate lignin equation correlated to IVTD.
Van Soest equation ( $r=0.93$ versus 0.84 ). Lastly, in vitro digestibilities of twigs were predicted especially poorly by equations containing permanganate lignin instead of sulfuric acid lignin.

The mean condensed tannins value for the more preferred leaf species was $6.8 \pm 7.0 \%$, the total tannin or radial diffusion tannins was $3.9 \pm 4.4 \%$, and the [(acid-detergent fiber remaining after pre-extraction with neutral-detergent) minus (the neutral-detergent fiber remaining after pre-extraction with acid-detergent)] or NAD-AND value was $9.7 \pm 6.8$ (Table 4). For the generally not preferred leaf species, the condensed tannins value was $3.5 \pm 4.1 \%$, the radial diffusions tannins value was $7.5 \pm 11.6 \%$, and the NAD-AND value was $7.8 \pm 5.2 \%$. These differences between preferred and not preferred, however, were not significant $(t=-1.1, \mathrm{p}=0.3)$. Paper chromotography indicated that only 4 leaf species containing hydrolyzable tannins. These 4 species tended to give higher values for radial diffusion tannins than for condensed tannins (paired $t$-test, $t=-2.3, p=0.055$ ).

Twigs had a condensed tannins mean of $3.2 \pm 3.4 \%$, a radial diffusion tannins mean of $10.8 \pm 12.5 \%$, and a NAD-AND mean of $3.3 \pm$ $2.5 \%$ (Table 5). Because the radial diffusion tannins value was higher than the condensed tannins value it may indicate that the twigs, taken as a whole, were higher in hydrolyzable tannins than are leaves. However preliminary analysis with paper chromatography did not indicate that hydrolyzable tannins were present in twigs of more than 5 of the 20 species tested (Table 2). These 5 species had radial diffusion tannin values significantly higher than condensed tannins (paired $t$ test, $t=-2.3, p=0.04$ ).

Consistent with the literature, condensed tannins and radial diffusion tannins correlated poorly (Table 6). The [(acid-detergent fiber remaining after pre-extraction with neutral-detergent) minus (the neutral-detergent fiber remaining after pre-extraction with acid-detergent)] or NAD-AND value theoretically measures tannin but did not correlate to either condensed tannin or radial diffusion measures. Interestingly, there was a slight positive correlation between in vitro digestibility and radial diffusion tannins. The acid-detergent insoluble 
Table 4. Tannin, fiber and unavailavle crude protein values from mature, Costa Rican browse leaves. Values presented as percentage of dry matter, except tannin values which are percentages in quebracho equivalents. Genera listed according to Table 1.

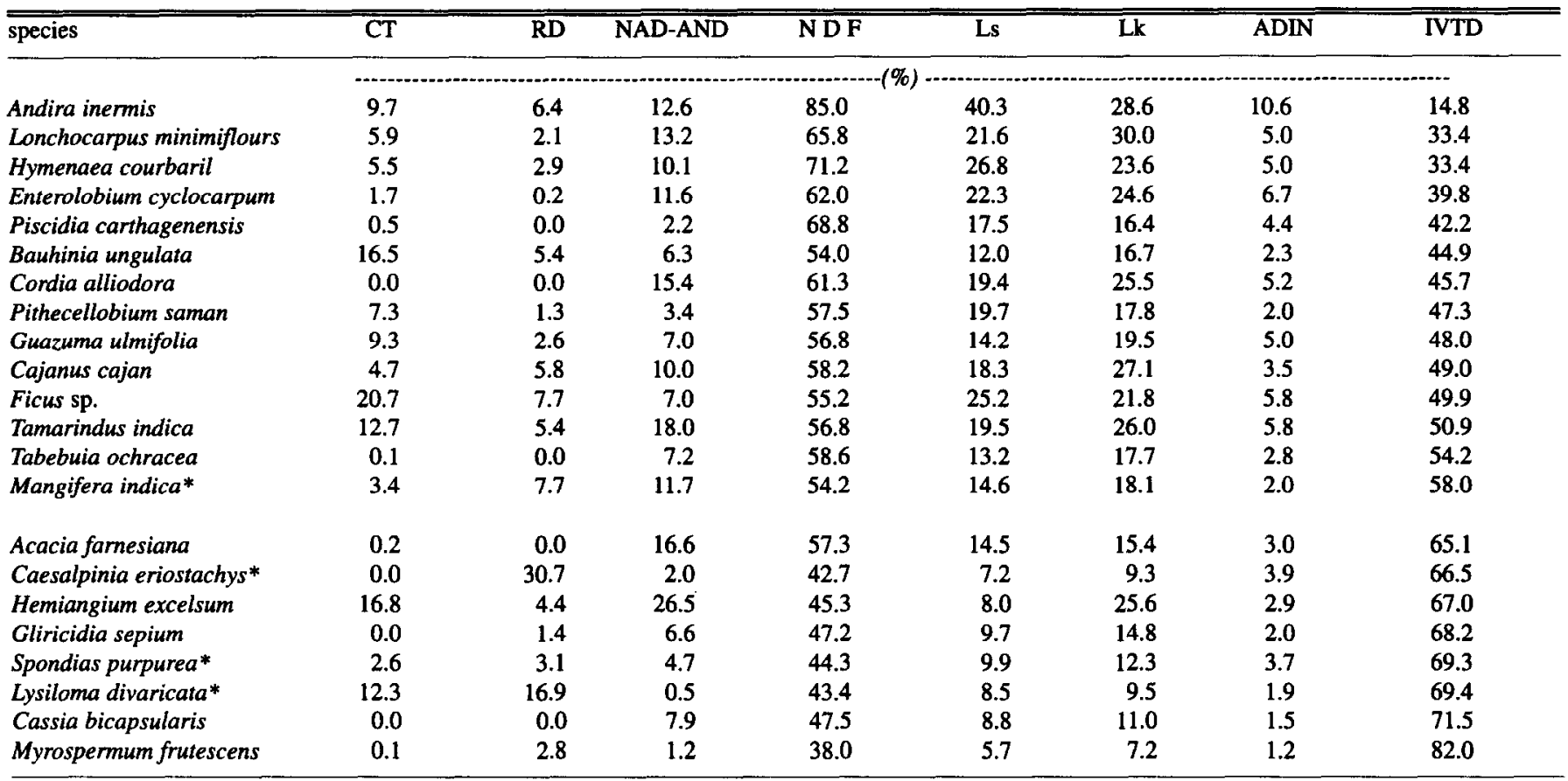

*hydrolyzable tannins indicated on paper chromotography

$\mathrm{CT}=$ butanol/HCI performed on a methanol extract;

$R D=$ radial diffusion; $N A D-A N D=$ see text; $N D F=$ neutral detergent fiber;

Ls = sulfuric acid lignin; $\mathbf{L k}=$ permanaganate lignin;

$\mathrm{ADIN}=$ the nitrogen remaining in the ADF $\times 6.25=$ unavailable protein.

IVTD $=$ in vitro true digestibility, from Table 1.

protein, thought to perhaps include tannin-bound protein, correlated poorly to condensed tannins, radial diffusion tannins and the NADAND values but was strongly negative with in vitro digestibility. Twigs showed several anomalies, in particular permanganate lignin was correlated slightly positively to in vitro digestibility.

When ranking the tree leaves, as done by Conklin et al. 1991, while the rankings were moved around some, the top 11 species remained in the top 11 (Table 7) regardless of how digestibility was determined. Only Cajanus cajan drops into the bottom 11 according to the Van Soest permanganate lignin equation and Enterolobium cyclocarpum drops according to the Horvath sulfuric acid lignin equation.

\section{Discussion}

The Van Soest summative equations predicted in vitro true digestibility of the tropical leaves in this study better than they predicted the in vitro digestibility of 7 species of maple leaves (Horvath 1981). Horvath's permanganate lignin summative equations gave higher correlations for the maple leaves he studied $(r=.964)$. The Horvath sulfuric acid lignin equation best predicted digestibility of the high tannin leaves in this study $(r=0.931)$. It was not expected that equations developed for temperate herbaceous forage (Van Soest's equations) or for 1 genus of temperate browse (Horvath's equation) would fit the in vitro digestibility of these tropical browses so well.

The condensed tannin levels in preferred leaves were comparable to mature leaves $(6.9 \pm 7.2 \%)$ and young leaves $(7.6 \pm 9.4 \%)$ eaten by Presbytis monkeys in India (Oates et al. 1980). Folivores in Cameroon select condensed tannin percentages ranging from $5.8 \pm 5.9 \%$ to 12.4 $\pm 7.7 \%$ condensed tannins for mature and young leaves respectively, while Ugandan folivores consume $2.4 \pm 4.2 \%$ to $3.3 \pm 3.9 \%$ condensed tannins for matue and young leaves respectively (Waterman et al. 1980). The condensed tannin values in this Costa Rican study fall into the range apparently accepted by folivores.

An increase of oak tannin, a hydrolyzable tannin, content in the diet of goats from 0 to $8.9 \%$ decreased the in vitro digestibility by 5.7 percentage units (Nastis and Malechek 1988), a small but significant drop. In this study there was a slightly positive correlation between radial diffusion tannins and in vitro digestibility. This is the opposite of what one would expect based on the goat work, assuming the high radial diffusion values may be associated with hydrolyzable tannins in these leaves. The fate of hydrolyzable tannins in the detergent system has not been examined.

The digestibility of the twigs is not predicted by these equations. In this study even the fiber content of these low elevation, tropical twigs did not predict in vitro digestibility well. The predicted digestibility was always higher than the in vitro digestibility, suggesting that the digestibility of cell solubles was being adversely affected in the in vitro digestion. According to Waterman et al. (1983), afro-montane twigs are lower in total phenolics and higher in fiber than leaves, and the digestibility of the stems was influenced strongly by fiber. Temperate twigs have also been reported to contain low tannins (Robbins et al. 1987b).

Zucker (1983) speculated that hydrolyzable tannins might more adversely affect rumen microbes than do condensed tannins, but considered as a group, these twigs did not appear to be high in hydrolyzable tannins. There is an unidentified deterrent to digestibility in these twig species that was not detected by current analytical methods. The in vitro digestibility of 8 out of 22 of the leaves tested, including 3 of the species possibly containing hydrolyzable tannins in the leaves, gave in vitro digestibilities averaging $70.7 \%$, a fairly high digestibility.

The validity of comparing predicted digestibility to in vitro digestibility instead of in vivo digestibility is an important consideration. Oak tannins decrease in vivo cell soluble digestibility even in 
Table 5. Tannin, fiber and unavailable crude protein values from mature Costa Rican twigs. Values presented as percentage of dry matter, except tannin values which are percentages in quebracho equivalents. Genera listed according to Table 2.

\begin{tabular}{|c|c|c|c|c|c|c|c|c|}
\hline species & $\mathbf{C T}$ & $\mathrm{RD}$ & NAD-AND & NDF & Ls & $\mathbf{L k}$ & ADIN & IVTD \\
\hline Andira inermis & 5.3 & 11.7 & 4.1 & 80.8 & 29.4 & 28.0 & 5.7 & 18.7 \\
\hline Bauhinia ungulata & 7.2 & 13.2 & 1.2 & 80.3 & 18.6 & 25.5 & 1.8 & 19.9 \\
\hline Tamarindus indica & 3.5 & 18.4 & 3.3 & 81.0 & 20.1 & 22.3 & 2.8 & 23.9 \\
\hline Guazuma ulmifolia & 3.9 & 21.4 & 4.6 & 71.7 & 15.9 & 16.8 & 2.4 & 27.4 \\
\hline Gliricidia sepium & 0.2 & 0.3 & 0.8 & 79.9 & 17.4 & 23.4 & 2.0 & 27.8 \\
\hline Cordia alliodora & 0.0 & 0.3 & 5.6 & 72.5 & 13.1 & 32.9 & 2.9 & 29.0 \\
\hline Enterolobium cyclocarpum & 0.4 & 0.3 & 2.6 & 78.9 & 19.4 & 22.5 & 2.6 & 29.9 \\
\hline Lonchocarpus minimiflours & 3.9 & 5.9 & 2.4 & 80.1 & 17.8 & 23.3 & 2.8 & 30.3 \\
\hline Spondias purpurea* & 0.2 & 0.3 & 10.7 & 77.4 & 19.8 & 23.2 & 5.4 & 31.3 \\
\hline Ficus sp. & 9.7 & 10.9 & 1.3 & 65.6 & 28.2 & 29.8 & 5.1 & 31.7 \\
\hline Lysiloma divaricata* & 9.7 & 30.3 & 0.6 & 71.0 & 13.7 & 18.9 & 1.6 & 32.1 \\
\hline Caesalpinia eriostachys & 0.0 & 34.5 & 3.4 & 72.0 & 9.1 & 17.9 & 2.5 & 38.9 \\
\hline Mangifera indica* & 7.3 & 30.3 & 4.7 & 59.3 & 14.5 & 31.8 & 1.4 & 44.8 \\
\hline
\end{tabular}

*hydrolyzable tannins indicated on paper chromotography

$C T=$ butanol/HCI performed on a methanol extract;

$\mathrm{RD}=$ radial diffusion; $\mathrm{NAD}-\mathrm{AND}=$ see text; $\mathrm{NDF}$ = neutral detergent fiber;

Ls = sulfuric acid lignin; Lk = permanaganate lignin;

$\mathrm{ADNN}=$ the nitrogen remaining in the ADF $\times 6.25=$ unavailable protein

IVTD $=$ in vitro true digestibility, from Table 2.

goats, generally considered to be the domestic animal best adapted to tannin (Nastis and Malechek 1988). Comparing in vivo digestibility of oak browse in goats to in vitro digestibility, Nastis and Malechek (1988) found that in vitro digestibility poorly predicted in vivo. In vitro true digestibility procedures, which uses neutral-detergent extraction after the fermentation, did consistently overestimate in vivo digestibility, by about $19 \%$ for all 5 diets tested. They used the TilleyTerry (1963) enzymatic procedure, which estimated 10\% higher for the diet without tannin but with increasing oak tannin in the diet, dropped until it intercepted in vivo digestibility. Therefore it was not predictive over the 5 different tannin levels. Thus, while in vitro digestibility was a poor predictor of actual digestibility, because in vitro true digestibility paralleled in vivo digestibility, the in vitro true digestibility procedure may still be a convenient method for at least ranking tanniniferous forages. In vivo digestibility trials need to be performed to test this further.

There is a possibility that the drying temperature of $55^{\circ} \mathrm{C}$ caused the formation of some artifact lignin. However, these samples were collected during the very humid rainy season in Costa Rica where mold becomes a substantial problem if drying proceeds too slowly. Given

Table 6. Correlations between tannin values, fiber, unavailable crude protein (ADIN), and in vitro true digestibility (IVTD) obtained from mature, Costa Rican browse leaves.

\begin{tabular}{|c|c|c|c|c|c|c|c|c|}
\hline \multicolumn{9}{|c|}{ correlations for leaves } \\
\hline $\mathrm{CT}$ & I & & 0.16 & 0.24 & 0.23 & 0.33 & 0.21 & 0.04 \\
\hline NAD-AND & I & & & & 0.25 & 0.69 & 0.30 & 0.25 \\
\hline Ls & I & & & & & 0.73 & 0.85 & 0.91 \\
\hline Lk & I & & & & & & 0.67 & 0.70 \\
\hline ADF-CP & I & & & & & & & 0.76 \\
\hline & & CT & $\mathrm{RD}$ & NAD-AND & Ls & Lk & ADIN & NDF \\
\hline IVTD & I & -0.06 & 0.29 & -0.07 & -0.63 & 0.13 & -0.38 & -0.65 \\
\hline CT & I & & 0.59 & -0.34 & 0.4 & 0.08 & 0.04 & -0.5 \\
\hline RD & I & & & -0.15 & -0.14 & -0.26 & -0.22 & -0.59 \\
\hline NAD-AND & I & & & & -0.02 & 0.12 & 0.38 & 0.01 \\
\hline Ls & I & & & & & 0.08 & 0.73 & 0.18 \\
\hline
\end{tabular}

CT $=$ butanol/HCI performed on a methanol extract;

$\mathrm{RD}+$ radial diffusion; NAD-And = see text; NDF = neutral detergent fiber;

$\mathrm{Ls}=$ sulfuric acid lignin; $\mathrm{Lk}=$ permanganate lignin; $\mathrm{ADIN}=$ the nitrogen remaining in the $\mathrm{ADF} \times 6.25=$ unavailable protein. 
Table 7. Comparing the rank of leaves established by combining in vitro digestibility (TVTD) and crude protein (CP) Conklin et al. 1991, and that calculated by the 2 most predictive equations.

\begin{tabular}{lccc}
\hline species & IVTD+ CP rank & V-Lk rank & H-Ls rank \\
\hline Acacia farmesiana & 1 & 2 & 2 \\
Caesalpinia eriostachys & 2 & 1 & 4 \\
Cassis bicapsularis & 3 & 4 & 3 \\
Myrospermum frutescens & 4 & 3 & 5 \\
Gliricidia sepium & 5 & 6 & 1 \\
Pithecellobium saman & 6 & 5 & 6 \\
Tabebuia ochracea & 7 & 8 & 7 \\
Spondias purpurea & 8 & 9 & 8 \\
Lysiloma divaricata & 9 & 7 & 9 \\
Cajanus cajan & 10 & 12 & 12 \\
Enteralobium cyclocarpum & 11 & 11 & 10 \\
Bauhinia ungulata & 12 & 10 & 13 \\
Cordia alliodora & 13 & 13 & 14 \\
Hemianguim excelsum & 14 & 14 & 15 \\
Piscidia carthagenensis & 15 & 15 & 11 \\
Lonchocarpus minimifllorus & 16 & 17 & 17 \\
Tamarindus indica & 17 & 18 & 16 \\
Ficus sp. & 18 & 16 & 18 \\
Guazuma ulmifolia & 19 & 20 & 19 \\
Mangifera indica & 20 & 19 & 20 \\
Hymenaea courbaril & 21 & 21 & 21 \\
Andira inermis & 22 & 22 & 22 \\
\hline
\end{tabular}

V-Lk = Van Soest equation using permanganate lignin

$\mathrm{H}-\mathrm{L} s=$ Horvath equation using sulfuric acid lignin and a tannin correction.

ranking equation = ((total mean IVTD\% - species IVTD\%)/st.dev $)+(($ total CP\% $)$ ranking cquation $=(($ total
species $\mathrm{CP} \%) / \mathrm{st} . \mathrm{dev}$.

rank = from high potential nutritional value (1) to low (22)

based on result from above ranking equation.

the limited storage facilities available and the length of the field season, thorough drying was necessary. In vivo digestibility trials on fresh browse leaves are needed to confirm the results reported here.

Methodological problems exist in measuring a tannin fraction that consistently affects digestion. Many tannin assay methods yield numbers that correlate poorly with each other (Bate-Smith 1977, Martin and Martin 1982, Mole and Waterman 1987).Biochemical measures of tannins have been used successfully to predict protein digestibility in deer (Robbins et al. 1987a, Hanley et al. 1992), but different biochemical methods may not be interchangeable in the equations.

The rapid and inexpensive evaluation of potential fodder trees without feeding trials would be extremely useful in countries that have limited facilities for in vitro or in vivo trials. The detergent system of fiber analysis allows investigators to evaluate browse species using standard fiber methodology in general survey work. While in vivo trials can not be replaced if one is interested in more accurate digestibility values, the calculated digestibility equations are offered as an initial screening procedure. These detergent system procedures, however, would not work for wild herbivores that are adapted to tanniniferous forages. For those herbivores Robbins et al. (1987a,b) found that the cell solubles, especially protein, digestibility was more affected by tannins than was the cell wall digestibility. Tannin-binding salivary proteins apparently prevents the reduction in cell wall digestibility frequently seen in vivo in sheep and in vitro in cattle with added tannin.

\section{Conclusions}

Based on the findings of these studies and the fact that this study considers only cattle, it is concluded that comparisons of predicted digestibilities using summative equations should be adequate in preliminary screening of browse. Specifically, for rapid screening of low to medium tannin browse, either Van Soest equation should be used. For screening browses suspected or known to contain tannins, the Horvath sulfuric acid lignin equation should be used.

\section{Literature Cited}

Asquith, T.N. and L.G. Butler. 1985. Use of dye-labeled protein as spectrophotometric assay for protein precipitants such as tannin. J. Chem. Ecol. 11:1535-1544.

Austin, P.J., L.A. Sucher, C.T. Robbins, and A.E. Hagerman. 1989. Tanninbinding proteins in saliva of deer and their absence in saliva of sheep and cattle. J. Chem. Ecol. 15:1335-1347.

Bate-Smith, E.C. 1975.Phyotchemistry of proanthocyanidins. Phytochem. 14:1107-1113.

Bate-Smith, E.C. 1977. Astringent tannins of Acer species. Phytochem. 16:1421-1426.

Conklin, N.L., R.E. McDowell, and P.J. Van Soest. 1991. Ranking twentytwo tropical browse species from Guanacaste, Costa Rica, for their potential nutritional value to cattle. Turrialba: Rev. Interamer. Cien. Agr. 41:615-625.

Conklin, N.L. 1987. The potential nutritional value to cattle of some tropical browse species from Guanacaste, Costa Rica. Ph.D. Thesis, Cornell University, Ithaca, N.Y. Univ. Microfilms, Ann Arbor, Mich..(Diss Abstr. 48:1558).

DeltaGraph, Inc. 1992. DeltaGraph Professional. 2 Harris Court, Suite B-1 Monterey, Calif., 93940.

Goering, H.K. and P.J. Van Soest. 1970. Forage fiber analysis (Apparatus, Reagents, Procedures and Some Applications. Agricultural Handbook No. 379. ARS, USDA, Washington DC.

Hagerman, A.E. 1987. Radial diffusion method for determining tannin in plant extracts. J. Chem. Ecol. 13:437-449.

Hanley, T.A., C.T. Robbins, A.E. Hagerman, and C. McAuthur. 1992. Predicting digestible protein and digestible dry matter in tannin-containing forages consumed by ruminants. Ecol. 73:537-541.

Horvath, P.J. 1981. The nutritional and ecological significance of Acer-tannins and related polyphenols. M.S. Thesis. Cornell Uneversity, Ithaca, N.Y.

Kumar, R. and M. Singh. 1984. Tannins: their adverse role in ruminant nutrition. J. Agr. Food Chem. 32:447-453.

Martin J.S. and M.M. Martin. 1982. Tannin assays in ecological studies: lack of correlation between phenolics, proanthocyanidins and protein precipitating constituents in mature foliage of six oak species. Oecol. 54:205211.

McArthur, C. 1988. Variation in neutral-detergent fiber analysis of tannin-rich foliage. J. Wildl. Manage. 52:374-378.

Mehansho, H., T.N. Asquith, L.G. Butler, J.C. Rogler, and D.M. Carlson. 1992. Tannin-mediated induction of proline-rich protein synthesis. J. Agr Food Chem. 40:93-97.

Mole, S. and P.G. Waterman. 1987. A critical analysis of techniques for measuring tannins in ecological studies: $I$. Technologies for chemically define tannins. Oecol. 72:137-147.

Nastis, A.S. and J.C. Malechek. 1988. Estimating digestibility of oak browse diets for goats by in vitro techniques. J. Range Manage. 41:255-258.

Oates, J.F., P.G. Waterman, and G.M. Choo. 1980. Food selection by the South Indian leaf-monkey, Presbytis johnii, in relation to leaf chemistry. Oecol, 45:45-56.

Oosting, H.J. 1948. The Study of Plant Communities. W.H. Freeman \& Co., San Francisco.

Porter, L.J., L.N. Hrstich, and B.C. Chan. 1986. The conversion of procyanidins and prodelphinidins to dyanidin and delphinidin. Phytochem. 25:223-230.

Reed, R.D. 1986. Relationships among soluble phenolics, insoluble proanthocyanidins and fiber in East African browse species. J. Range Manage. 39:5-

Reed, R.D. 1987. Phenolics, fiber, and fiber digestibility in bird resistant and nonbird resistant sorghum grain. J. Agr. Food Chem. 35:461-464.

Robbins, C.T., A.E. Hagerman, P.J. Austin, C. McArthur, and T.A. Hanley. 1991. Variation in mammalian physiological responses to a condensed tannin and its ecological implications. J. Mamm. 73:480-486.

Robbins, C.T., T.A. Hanley, A.E. Hagerman, O. Hjeljord, D.L. Baker, C.C. Schwartz, and W.W. Mautz 1987a. Role of tannins in defending plants against ruminants: reduction in protein availability., Ecol 68:98-107.

Robbins, C.T., S. Mole, A.E. Hagerman, and T.A. Hanley. 1987b. Role of tannins in defending plants against ruminants: reduction in dry matter digestion? Ecol. 68:1606-1615.

Robertson, J.B. and P.J. Van Soest 1980. The detergent system of analysis and its application to human foods. In: The Analysis of Dietary Fiber in 
Foods, ed. W.P.T. James and O. Theander. Marcel Dekker, Inc., NY. pp 123158.

StatView SE + Graphics. 1991. Abacus Concepts, Inc. 1984 Bonita Ave., Berkeley, Calif. 94704.

Tilley, J.M. A. and R.A. Terry. 1963. A two-stage technique for the in vitro digestion of forages crops. J. Brit. Grass. Soc. 18:104-111.

Van Soest, P.J. 1982. Nutritional Ecology of the Ruminant. O\&B Books, Inc., Corvallis, Ore.

Waterman, P.G., C.N. Mbi, D.B. McKey, and J.S. Gartlan. 1980. African rainforest vegetation and rumen microbes: Phenolic compounds and nutrients as correlates of digestibility. Oecol. 47:22-33.
Waterman, P.G., G.M. Choo, A.L. Vedder, and D. Watts. 1983. Digestibility, digestion-inhibitors and nutrients of herbaceous foliage and green stems from an African montane flora and comparison with other tropical flora. Oecol. 60:244-249.

Waterman, P.G., J.A.M. Ross, and D.B. McKey. 1984. Factors affecting levels of some phemolic compounds, digestibility, and nitrogen content of the mature leaves of Barteria fistulosa (Passifloraceae). J. Chem. Ecol 10:387401.

Zucker, W.V. 1983. Tannins: Does structure determine fuction? An ecological perspective. Amer. Natur. 121:355-365. 